\title{
Dialogic \& Critical Pedagogies: An Interview with Ira Shor
}

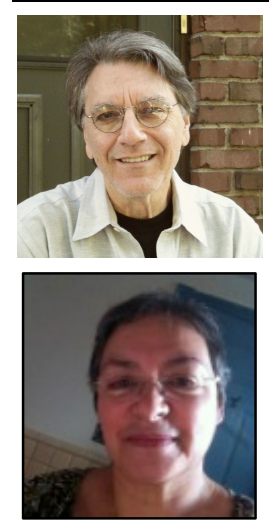

\section{Ira Shor}

College of Staten Island, City University of New York, USA

\author{
Ana Marjanovic-Shane \\ Chestnut Hill College, USA
}

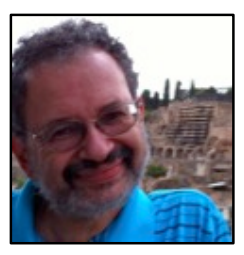

Eugene Matusov

University of Delaware, USA

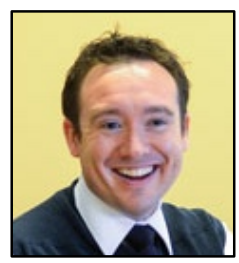

James Cresswell

Ambrose University, Canada

\section{Abstract}

In 2016, the Main Editors of Dialogic Pedagogy Journal issued a call for papers and contributions to a wide range of dialogic pedagogy scholars and practitioners. One of the scholars who responded to our call is famous American educator Ira Shor, a professor at the College of Staten Island, City University of New York. Shor has been influenced by Paulo Freire with whom he published, among other books, "A Pedagogy for Liberation" (1986), the very first "talking book" Freire did with a collaborator. His work in education is about empowering and liberating practice, which is why it has become a central feature of critical pedagogy.

Shor's work has touched on themes that resonate with Dialogic Pedagogy (DP). He emphasises the importance of students becoming empowered by ensuring that their experiences are brought to bear. We were excited when Shor responded to our call for papers with an interesting proposal: an interview that could be published in DPJ, and we enthusiastically accepted his offer. The DPJ Main Editors contacted the DPJ community members and asked them to submit questions for Ira. The result is an exciting in-depth interview with him that revolved around six topics: (1) Social Justice; (2) Dialogism; (3) Democratic Higher Education; (4) Critical Literacy versus Traditional Literacy; (5) Paulo Freire and Critical Pedagogy; and (6) Language and Thought. Following the interview, we reflect on complimentary themes and tensions that emerge between Shor's approach to critical pedagogy and DP.

Ira Shor is a professor at the College of Staten Island, City University of New York, where he teaches composition and rhetoric. He is also doctoral faculty in the Ph.D. Program in English and in the Ph.D. in Urban Education, at The Graduate Center, CUNY. Shor grew up in the working-class area in the South Bronx of New York City. According to Shor, coming from a working-class area had a powerful influence on his thinking, politics and feelings. In collaboration with Paulo Freire, he has been one of the leading exponents of critical pedagogy. Together they co-wrote "A Pedagogy for Liberation."

Eugene Matusov is a Professor of Education at the University of Delaware. He studied developmental psychology with Soviet researchers working in the Vygotskian paradigm and worked as a schoolteacher before immigrating to the United States. He uses sociocultural and Bakhtinian dialogic approaches to education. His recent books are: Matusov, E. \& Brobst, J. (2013). Radical experiment in dialogic pedagogy 
in higher education and its Centauric failure: Chronotopic analysis and Matusov, E. (2009). Journey into dialogic pedagogy.

Ana Marjanovic-Shane is an Associate Professor of Education at Chestnut Hill College in Philadelphia. She studies meaning making in education and play, dialogic educational relationships and events, dialogic teacher orientation, and the role of imagination, drama, play and critical dialogue in education. She uses sociocultural and Bakhtinian dialogic orientation in her studies. Her articles were published by "Mind, Culture, Activity Journal", "Learning, Culture and Social Interaction", and as book chapters in books on play and education. Her most recent publication is: Marjanovic-Shane, A. (2016). "Spoilsport" in Drama in Education vs. Dialogic Pedagogy. Dialogic Pedagogy: An International Online Journal, 4.

James Cresswell is an Associate Professor \& Program Chair in Psychology at Ambrose University (Calgary Canada). His work is largely influenced by the philosophy of Mikhail Bakhtin and cultural psychology. Of special interest is Bakhtin's work on aesthetics in relation to language and how it can enhance current work in education, philosophy of mind, cognitive science of religion, and immigration. His work has been supported by organizations such as the Social Science \& Humanities Research Counsel, Templeton Foundation, and Murdoch Charitable Trust.

$\cos \cos 80$

\section{Introduction}

Last year, the Main Editors of Dialogic Pedagogy Journal issued a call for papers and contributions to a wide range of dialogic pedagogy scholars and practitioners. One of the scholars who responded to our call is famous American educator Ira Shor, a professor at the College of Staten Island, City University of New York. Shor has been influenced by Paulo Freire with whom he published, among other books, "A Pedagogy for Liberation" (1986). His work in education is about empowering and liberating students, which is why it has become a central feature of critical pedagogy.

Shor's work has touched on themes that resonate with Dialogic Pedagogy (DP). He emphasizes the importance of students becoming critically literate through a dialogic inquiry into their conditions and experiences. This theme is echoed in DP with a shared critique of education that subjugates students to regimes that alienate them from their own experience. Some of Shor's work has inspired DP (see Shor \& Freire, 1987). It was for this reason that we were excited when Shor responded to our call for papers with an interesting proposal: an interview that could be published in DPJ! We enthusiastically accepted his offer. We (the DPJ Main Editors) contacted the DPJ community members and asked them to submit questions for Ira. The result is an exciting in-depth interview with him that revolved around six topics: (1) Social Justice; (2) Dialogism; (3) Democratic Higher Education; (4) Critical Literacy versus Traditional Literacy; (5) Paulo Freire and Critical Pedagogy; and (6) Language and Thought. Following the interview, we reflect on complimentary themes and tensions that emerge between Shor's approach to critical pedagogy and DP.

\section{Dialogic Pedagogy Journal Interview with Ira Shor}

\section{Social Justice}

1a. Eugene Matusov: Apparently, the history of the XX century has discredited the real socialism of the Soviet Union, China, Romania, Cuba, Albania, Yugoslavia, Hungary, DDR (i.e., Communist East Germany), Cambodia, Guinea-Bissau, and so on. All of these Communist/Socialist regimes were involved in mass persecutions, oppression, and even in mass murder on a gigantic scale and were 
totalitarian in their nature. However, all of these regimes were driven by concerns about social justice. Would you agree with this depicture of these Communist/Socialist regimes? If so, what went wrong in these regimes' pursuit of social justice, in your view, and why? If not, how and why not? What lessons have you learned from the historical failures (if not crimes) of the Communist/Socialist regimes of the $\mathrm{XX}$ century?

Ira Shor: Just this morning I read in the NYTimes about a dissident Uighur scholar imprisoned for life by the "Communist" regime of China, and about the arrest of a dissident blogger in Vietnam by that one-party, post-revolutionary state. After marching for 10 years to end the war in Vietnam when I was a student and young professor, I'm particularly disgusted reading about the totalitarian excesses of the regime in power there. These kinds of regimes, historically self-designated as "Socialist" or "Communist" or "Democratic" or "People's Republics," some the product of revolution and some installed by an occupying Red Army after WWII, have been left-wing oligarchies, anti-pluralist, ruled top-down by privileged elites (who I observed in Budapest in 1971 as those few wearing leather jackets in winter and in Leningrad in 1989 as those ostentatiously smoking American cigarettes bought in restricted "dollar-stores"). None of the revolutions of the $20^{\text {th }}$ Century installed radical democracies. Obviously, seizure of state power is not sufficient to effect a transition to democracy, though the new left-wing oligarchies in control of these states can distribute social benefits more systematically or generously than prior regimes.

A socialist-democratic transformation requires dismantling what Foucault called the disciplinary matrix of domination spread over the whole social body by the modernist state which emerged at the end of the $18^{\text {th }}$ Century.

We have degenerate capitalist oligarchies in the West and have witnessed the collapse of degenerate communist oligarchies in the East. Those collapsed communist regimes as well as the nominally communist parties in China and Vietnam have morphed into market-based oligarchies run by "communist" cadres. (China is the world's factory with 50,000 State "minders" censoring the internet there; Vietnam offers global entrepreneurs perhaps the cheapest labor force after Haiti.) A neoliberal global system rules all nations now no matter what the formal government or formal leadership call themselves or their state. Democratic opposition to these neoliberal regimes and to the unrelenting austerity imposed on the $99 \%$ for 40 years now is also a global phenomenon. Neoliberalism, or the harsh rule of the market which suppresses democratic citizenship in favor or runaway consumerism, is now "the power that is in power," as Paulo Freire would say, while democracy, equality, ecology, and peace (how I define the agenda for "social justice") is "the power not yet in power," in Freire's terms.

1b. Eugene Matusov: What is the relationship between equality and diversity (including diversity of inequality) in general and in education? Do you think the desires of promoting equality and promoting diversity contradict each other? If so, how and if 'no', why not?

Ira Shor: "Equality" and "diversity" remain unfulfilled obligatory themes in the continuing opposition to neoliberalism. That opposition, to be a project for "social justice" with an agenda I described above as "democracy, equality, ecology, and peace," cannot leave diversity and inclusion out of the mix. Without question, democracy and equality imply diversity, or else neither is operating. The only way social justice can succeed if it is a diverse movement, an inclusive opposition, where all constituencies are included as stakeholders. Democracy demands equality because a liberatory future requires the majority to make history with their own hands, as Freire put it. 
Social justice has motivated various mass movements for decades, in and out of education. The status quo, run by and for a dominant elite, uses every difference against us. "Divide and conquer" is an old, effective tactic in the domination toolbox. The more social justice movements build cross-class, crossracial, and cross-gender alliances, which are now referred to as "inter-sectional" movements, the more they will challenge and change the destructive status quo.

In the case of mass education, schooling has never been egalitarian, democratic, critical or inclusive, despite "the Great School Legend" which mystifies public schools as "great equalizers," as scholar Colin Greer named and critiqued this myth in 1972, that universal free education has been the foundation of American prosperity and freedom, that the public schools embraced all immigrant groups and turned America into "a melting pot nation" where anyone can succeed by their own grit ("the American Dream"). Greer and other scholars like Bowles and Gintis, at work during the mass movements in the U.S. in the 1960s and 1970s, were referred to as "Revisionists" then for revising the official narrative of American education. This demystification continued in the work of Harvey Graff, Brian Street, Shirley Brice Heath and others, whose literacy studies demonstrated the close fit between language learning and class hierarchy. All in all, mass education has not produced equality, inclusion, democracy, or leveling of class, race, and gender divisions. In the U.S., high school and college graduation rates now are at record highs for both genders and all racial/ethnic groups, yet economic inequality is at its highest in 90 years, women graduates have not been able to convert their educational gains into economic ones, and black unemployment rates remain twice the white rate like they have always been, while white family median income stays constant at about $170 \%$ of Black family income. Residential neighborhoods and schools are as segregated as ever. Put simply, the vast spread of public lower and higher education has not altered the material position of disfavored groups.

Equality and inclusion remain the unfinished tasks of democratic movements from below. In the 1960s1970s, an age Foucault celebrated for "the general criticizability of things," such opposition put the status quo on the defensive, opening up space for unearthing and circulating what Foucault named as "subjugated knowledges" and "disqualified discourses." Forty years of resurgent domination has derailed progressive changes, which I wrote about in my book Culture Wars (1986, 1990). I called the counter-attack of authorities "the Conservative Restoration," when a destabilized elite reasserted domination. The Conservative Restoration continues, penetrating American society decade by decade, dismantling efforts in education to build multicultural curricula, labor studies, and women's programs, imposing market discipline on schools, colleges, health care, housing, mass transit, recreation, food chains, energy sources, incarceration [i.e., monetization, conversion of public goods into private revenue streams, diminishing democratic rights and constitutional protections, re-defining citizens as consumers empowered by choice in markets, etc]. Neoliberalism is the agenda of both major parties in the U.S. under whose rule vast wealth was transferred from the public to the private sectors, from the working-class and middle-class to the super-rich, from public schools to private units (via the aggressive "charter school" movement funded by billionaires like Gates, Broad, and the Waltons). Formal, mass education from k-12 to graduate school has always served the interests of the dominant elite but that service is now being radically enhanced by aggressive privatization (a marketization strategy consistent with neoliberalism).

Because equality and diversity are under attack, because democracy is being restricted by great wealth, these values should remain the agenda of activist educators for school and society, for educational policy as well as for everyday learning and teaching. I base my critical teaching on democracy, equality, ecology, and peace, when I design lessons, projects, and activities for students. Readers familiar with my books can find there specific strategies based in democratization and diversity. 
1c. Eugene Matusov: What is the relationship between equality and quality in general and in education? Do you think the desires of promoting equality and promoting quality contradict each other? If so, how, and if 'no', why not?

Ira Shor: A dominant discourse in our society has constructed these two concepts at odds with each other. Constructing equality as undermining quality protects the unequal status quo against majoritarian policies. For example, when Congress passed the Serviceman's Readjustment Act of August 1944, some elite policy-makers opposed free college education as part of the program. You can read the opposition to "the G.I. Bill" as it was known, by policy-prince James Bryant Conant, then President of Harvard, soon-to-be the High Commissioner of Occupied Germany, and afterwards the head of the influential Carnegie Foundation. Conant worried that the influx of non-elite veterans onto college campuses would undermine the quality of the American university system. As it happened, a million veterans (almost all white) did attend college after WWII on the Federal dime where they proved themselves to be outstanding students. Still, despite this example of non-elite white male veterans succeeding in college, the policy princes persisted with their apartheid education policies, that is, segregating working-class and lower middle-class high school graduates onto a new lesser track of higher education called "the community college," instead of enrolling all of equally-funded, equally academic campuses. This preferential option for the elite among policy-makers invented what became known as the "triple-track" university system as the national standard, with over-financed university centers enrolling the top $10 \%$ of high-school graduates, lesser--funded four-year state colleges enrolling the next $10 \%$, and least-funded community colleges catching the post-war mass of non-elite students onto vocationalized campuses. The maintenance of "quality" in this policy-making was actually the maintenance of class, gender and race privilege.

"Quality" is not a neutral, apolitical category which angelically measures and smiles on the best and the brightest. "Quality" is a "regime of truth", as Foucault might say, which rewards the already-privileged with more privileges. Foucault articulated how the institutions of society, like mass education, served as "disciplinary instruments" to rank, sort, and extract productive, compliant labor from each generation. Foucault designated institutional "ranking" as a primary tool to discipline and divide a population into unequal stations ("cellularization" to disintegrate solidarity). In the universe of education discourse, "quality," then, is a code-word which disguises arbitrary subordination.

"Quality" thus is a rhetorical meme for a coded narrative justifying inequality. This code also relates to Bourdieu's theory of unequally distributed, economically-dependent distinction in society. Bourdieu theorized that cultural capital of unequal value is distributed through everyday life and social institutions (the habitus) from which each person is structured into hierarchical social locations. We all emerge from our habitus as human subjects of one status or another, but the elite receive cultural capital of high distinction which develops them as subjects of power and authority because of their origins in an economically-privileged habitus. One of the specific unequal effects of elite habitus equips some human subjects with control of Standard Usage, the idiom of highest distinction in society. The non-elite majority of all races and genders does not learn or practice the valuable cultural capital of Standard Usage in its habitus. The high-rank Standard is a politically and economically elevated linguistic practice based in the preferences and usages of metropolitan elites in each industrializing nation. What Bourdieu called "the national unification of the linguistic market" installed the singular dialect of the dominant as the national standard against which all other usages and idioms were judged lesser ("slang, broken English, Black English, Spanglish," etc.) This political installation of certain cultural capital as highly-distinctive applied also to artifacts and canons, such as "The Great Books" or "The Great Works of music, painting, sculpture, architecture, etc.," the products and preferences of the elite 
became items of high distinction. Because such a partisan process is always already in place whenever we compare or evaluate any social practices (including speaking, writing, performances on standardized tests, etc.), there is no innocent position from which to judge any activity or artifact of society free from politics ("power relations").

At my low-budget working-class college, students do not score high enough on the SATs to compete for admission to colleges of high distinction.) We have known for decades that scores on standardized tests like the SAT correlate with family income: the higher the family income the more likely a student will produce higher scores. Social class dissolves here into a metric, a ranking indicated by measurement, an outcome of social hierarchy which is hidden behind a discourse of individual inadequacy. For critical literacy in my writing classes, I routinely bring in data bases and reports to pose standardized testing a political problem - "Why do students from wealthier homes score higher than those from low-income homes?"

Teaching against the unequal status quo and for majoritarian agency is of course another way to define critical pedagogy as Paulo Freire proposed it. In doing this, critical-democratic educators will have to generate quality and equality at the same time.

In this regard, Paulo Freire proposed for public schools "popular-democratic education" as he called his program while serving as the Workers' Party Secretary of Education of Sao Paulo, 1989-1991. In terms of literacy, this involved teaching Standard Usage parallel with the grammar and beauty of the students' own non-standard idioms. To Freire, Standard Usage became empowering when it was taught as a tool for non-elite students to use on their behalf. In my field of composition-rhetoric, some notable scholars have taken a similar position: Donald Lazere in his books on teaching for civic literacy; Geneva Smitherman, on teaching Black English Vernacular along with Standard English. I addressed this conundrum of standard/non-standard usages in my book Empowering Education in terms of what I called "the third idiom." One goal I set for myself in my everyday practice of critical teaching is to transform "teacher-talk" so as to promote dialogue. In speaking, I try to merge my high-status academic discourse with the colloquial working-class usages my students bring to class (and which I grew up speaking in my own working-class childhood). I seek a hybrid idiom through which to dialogue with the students, which integrates conceptual frameworks and vocabulary from high-status reasoning and bodies-of-knowledge with the non-elite colloquial knowledges, usages, lexicon and syntax familiar to everyday life. When I get this hybrid discourse right in actual classroom dialogues, I model to students a way of using language to examine issues and materials which respects their own idioms while integrating analytic discourse. When a hybrid discourse does emerge, the critical classroom invents for itself a new tool for democratization, "the third idiom," co-constructed in dialogic practice from the contradictory linguistic habits teachers and students bring to class.

1d. Judith Green: How can policymakers be reached and how do they need to take actions to insure social justice, not manage one-size-fits-all for all students, all teachers and all communities?

Ira Shor: In recent years, one of the most successful movements for social justice in the U.S. has been the campaign for same-sex marriage, which is part of a long-term advocacy against homophobia. Gay advocacy began in the 1970s after the landmark Stonewall Riots in New York in 1969. Advocates built a movement and coalitions that forced the hand of the Supreme Court to legalize same-sex marriage in 2015. Other mass campaigns in these decades included movements against both Iraq Wars launched in 1991 by the elder Pres. Bush and in 2003 by the younger Pres. Bush, which was supported by Hillary Clinton and the Democratic Party at that time. Continuing opposition to the second and 
continuing war in Iraq exposed the younger Bush's lies about WMDs and Saddam Hussein's complicity in terrorism and the 911 attacks. The opposition succeeded in turning public opinion against the war, limiting the options available to the White House occupied by either major party. Yet another recent mass movement has been the "Opt-Out" Campaign from 2011 forward, organized locally by mostly mothers with children in schools being taken over by costly, pointless, child-abusive testing. This grassroots Opt-Out movement forced authorities in some key states to abandon testing regimes on which they had spent hundreds of millions of dollars. Then, there was the well-known "Occupy Wall Street" movement erupting in September 2011, which eventually spread to 750 cities and towns in the U.S., until local police destroyed the encampments in lower Manhattan and elsewhere. While the police carried the day for the financial oligarchs, this campaign managed to change national debate over income inequality. Regarding militant opposition to racism, a "Black Lives Matter" movement also emerged in 2015 to shine bright lights especially on police violence against people of color.

Generally, mass campaigns for social justice involve rallies, marches, demonstrations, sit-ins, boycotts, mass lobbying, viral videos, meme-bearing t-shirts, flyers, handbills, posters, documentary film, theatrical performances, exhibitions, conferences, forums, neighborhood fairs, concerts, promotional treks, celebrity endorsements, legal challenges, petitions, and so on. These are the tools used by movements from the bottom up to pressure policy-makers. Since the 1970s, policymakers and government have moved to the right in a long period of "neoliberalism," which has meant that power is used from the top down to impose severe market discipline on the majority, to accelerate the transfer of national wealth into private hands. All sectors of society-production, transportation, communications, finance, housing, education, employment, etc.-have imposed a severe austerity on the vast majority which has greatly enriched the $1 \%$. Policy-makers are the agents of the private sector charged with imposing austerity and justifying the growing gap between the top and the rest of society along the lines first articulated by Margaret Thatcher as Prime Minister of the UK in the 1980s, "there is no alternative."

In certain cases, the "policy-maker" who must be pressured first and foremost is a retrograde union chief who refuses to organize the membership as a fighting force. This is the case with the two teacher union presidents in the U.S., Randy Weingarten of the AFT and Lily Eskelsen Garcia of the NEA. Both have taken funds from the billionaire Bill Gates who pushes policies favoring privatization of public schooling and standardized testing to judge student achievement and teacher quality. Both rule their large unions with iron fists, preventing rank-and-file activism to emerge. They are both agents for the corporate wing of the Democratic Party who forced Hillary Clinton down the throats of their combined 3 million members without substantive debate about her lack of a public education platform, as well as her lifelong association with two billionaires at the forefront of the privatization assault on public schools, Eli Broad and the Walton family. In cases like these, where a union organization already exists and fails to represent the needs of its members, the first activism has to be expelling renegade union leaders from office and replacing them with rank-and-file leaders. In some union locals, there have been alternative leaders, like Karen Turner, Bob Peterson, Jesse Hagopian, and Barbara Madeloni. Prolonged campaigns against policy-makers are needed to change the political direction of society to act.

1e. Tara Ratnam: In today's market society, those educational processes seem to be institutionalized that produce the types of individuals needed for reproduction of commodity through specialized skills adapted to the global market. Here, the ideals of individual profit and narrow interests are relentlessly promoted even at the cost of common humanity (e.g., the economic exploitation by the indomitable corporates that has fomented a debt crisis, subjecting many people into endless belt tightening and 
ruining the life chances of the youth in these countries.). There seems to be a crisis of values that creates not only these socioeconomic inequities, but also violence and war (seen around the world involving power and politics). What would an activist stance look like that can work to alter this reproductive trend in current society and education to a transformative one; a transformation that encompasses the dominant oppressor as much as the marginalized (for it seems to be the problem not only of the marginalized, as it is commonly made out to be, but of the whole of society consisting of few who try to exert control and the many that are marginalised by it)?

Ira Shor: When Barack Obama campaigned on a platform of "hope and change" in 2008, many expected a national policy change against the horrendous Wall Street domination of society which produced economic collapse, massive unemployment, families evicted from homes, loss of pension plans, and the drastic defunding of the public sector which led to fiscal crises like the one in Flint, Michigan, where city managers changed the water supply to a a cheaper polluted source and poisoned that city of 99,000 . Sadly, instead of a robust bottom-up offensive, Obama launced a top-down restoration. He appointed Wall Street financiers to lead his Administration's economic policies and to head the Treasury Department. These policy-makers directed hundreds of billions of relief to the banks and not to the working-class and middle-class victims of the casino capitalism played by Wall Street. While tens of millions lost jobs and homes, Wall Street banks were replenished with public funds. This crime against the public good created the deep hardships and anger which opened the door to Trump's victory in 2016.

The last 40 years have been very hard on the working-class, the middle class, and the poor. Where I teach, New York City, 33,000 children in our public schools are homeless. Data tell us that the best years to be working-class, middle-class, or poor in America were 1947-1979. In those decades, the bottom $20 \%$ of families increased their incomes at a higher percentage than any other quintile. The top quintile gained the smallest percentage of all family cohorts. In those years following WWII, productivity and wages tracked each other closely in a constant upward trend. As the wealth produced by each hour of labor (productivity) rose, the wages and benefits paid to the worker rose at a similar rate. This means that working-class and middle-class families in those decades were able to capture higher wages in return for their rising productivity, thus enabling them to do a little better each year vis-à-vis living standards. In the decades after 1970 , productivity continued to rise spectacularly but wages and benefits have not; and the minimum wage has fallen way behind in buying power. Flat wages mean that the greater wealth produced in these recent years (productivity) by the 144 million Americans now employed has gone almost entirely into the pockets of the top-owners, executives, shareholders, debtowners--not the bottom $90 \%$. At the same time, the cost of living continued rising (inflation of higher education, health care, clothing, food, transportation, housing, insurance, taxes, services, etc.) So, for the last two decades, even mainstream media feature the problem of rising economic inequality and "class war" (a topical theme I center in my college writing courses). A common anxiety in the mainstream media is the failure of the new generation to equal their parents' achievements and standards of living, deeply in debt after college with no good job prospects and no apartment of their own they can afford, more and more of the young graduates moving back home to live with mom and dad. "Class war," then, is a theme for critical educators to put into course syllabi.

\section{Dialogism}

2a. Eugene Matusov: Where do you see similarities and difference between Bakhtinian and Freirean dialogic frameworks in general and in education in specific?

Ira Shor: I'll pass on this question if you don't mind. Not one of my central interests. 
2b. Eugene Matusov: Do you think the goal of critical dialogue in education is social justice? If so, why? If not, why not? Or do you think critical dialogue is an end in itself in education? If so, why? If not, why not? What do you think is the relationship between critical dialogue and social justice in education?

Ira Shor: I already answered this question above in previous remarks.

2c. Eugene Matusov: Would you equate the notion of "critical pedagogy" with the notion of "critical dialogue"? Why? Why not?

Ira Shor: Critical dialogue is essential in critical pedagogy but there is more to critical pedagogy than dialogue. Dialogue fits into a sequence of teaching-learning which in the Freirean mold begins with the teacher studying the students before she presumes to teach them. In Freire's literacy programs, literacy teams settled into a village or neighborhood where they planned to offer classes. Before the first class, they did extensive sociocultural and socio-linguistic research into the area, recruiting local residents as co-researchers and interlocutors. From these weeks of prior research, the joint group of teachers and locals extracted the generative words and themes most relevant to the people in that area, best suited to engaging them in critical study of reading and writing because these subject matters were legible and meaningful to the students. Before any written texts or letters were introduced to the students, the teams began the first class with ten projected slides which invited discussion on the already-existing culture-making powers of the assembled students. These illiterate peasants and workers were able to read the world in speech if not in printed or composed texts, so Freire began the sessions with the theme of "the anthropological nature of culture," a theoretical notion made concrete and "readable" via the 10 pictorial slides representing human activities. The 10 initial slides are important methodological starting points which privilege student expression in response to legible subject matters, which initiated critical literacy as inquiry-based alphabetization. Freire scaffolded literacy in this student-centered manner, using familiar subject matters engaged in unfamiliar ways. Dialogue began with slides representing how humans make culture followed by lessons based in themes from student life. This method is a form of democratic discipline because it frontloads student cognition and activity which simultaneously enables and restrains the directive voice of the teacher. The critical pedagogy in this method of dialogue deploys and validates the thoughts, language use, and everyday lives of the illiterates. The students are cognitively animated to reflect instead of waiting for the educator to explain for them and to them what things mean and what to believe. Another critical dimension of this pedagogy is presenting what Freire called "hinged themes" by which he meant moving outward from the generative themes discovered in preliminary research so as to connect the words and topics most prominent in local life with the history and society they are part of.

2d. Judith Green: What issues do you think are currently important for those of us, who are involved in proposing and promoting dialogic pedagogy and its underlying social justice agenda?

Ira Shor: Economic inequality; the looting of the nation by corporate giants and Wall Street; the tax evasion of billionaires and major corporations; wages far too low for far too long; the difficulty young people have finding good jobs, affording their own apartments; runaway student debt; Black Lives Matter-police violence against people of color, the mass incarceration of mostly young Black and Hispanic men, the school-to-prison pipeline, the disproportionate drug arrests directed at black people. The under-financing of public schools for poor and working-class children; gender inequality in employment and the sexual violence directed at women; the accelerating despoliation of planet Earth and the stark evidence for global warming. 
2e. Jim Cresswell and Eugene Matusov: You wrote, "The teacher is the architect of this un-doing and redoing" (1987, p. 97). Do you see the primary goal of education in de-socializing, un-doing, deconstructing any sociocultural practices and values while re-socializing, re-doing, and re-constructing are occasional byproducts of genuine education? Or do you see re-socializing, re-doing, and reconstructing as the primary goal of education equal, if even not more important, to de-socializing, undoing, de-constructing?

Ira Shor: To me, critical dialogue in a critical pedagogy is an invitation for de-socialization and resocialization of both teachers and students. Freire spoke of this process as "denunciation" and "annunciation." When we practice critical pedagogy, and negotiate a meaningful curriculum with students, the social relations of discourse change in the classroom. Because human subjects and human consciousness are the products of social action including discourse, we make possible an alternative construction of ourselves. Such a learning process is unavoidably deconstructive/reconstructive. It invites egalitarian relations and democratic development, or the practice of democratic habits for group process. These alternative developments emerge inside a process of questioning school and society. This is a knowledge-making process constructed on different terms than prior traditional ones. The discourse enabled by this form of dialogue becomes a material force for re=perceiving self-in-society. Human subject formation-seeing, being, speaking, thinking, and doing-is "neuroplastic." ALL classroom methods, dominant/accomodation or questioning/critical, work from this "neuroplasticity" of consciousness, knowledge, orientations, habits, preferences, dispositions, etc., because all pedagogies are instruments for forming human beings one way or another. Critical pedagogy intends a different direction for human subject formation than the dominant one now in place in all schools. Critical pedagogy deploys problem-posing dialogue so as to invite students to develop as activist citizens inspired by democracy, equality, ecology and peace (the foundations of social justice). All teachers influence how students think and develop; all teachers face resistance to and cooperation with their interventions; critical pedagogy takes its place against standard "banking" pedagogies which accommodate students to their places in the unequal status quo.

\section{Democratic higher education (Open Syllabus Education, OSE)}

3a. Eugene Matusov: In your pedagogical experiment on democratization of higher education, described in your famous 1996 book "When students have power: Negotiating authority in a critical pedagogy," using summative assessment (i.e., grade marks at the end of the class) were non-negotiable in your classes. From your book, it seemed that the students might be able to negotiate how the summative assessment was designed but not whether the summative assessment was applied to them or not (e.g., grade sabotage was not an option). Was it because of the institutional pressure that you could not avoid (or not be able to sabotage) or because of your own pedagogical belief in summative assessment as an absolutely necessary component of good education? If the latter, can you elaborate on that, please.

Ira Shor: Like all teachers in a formal school or college, I am an institutional officer required to take attendance and give grades and submit official documents at the end confirming the outcomes for each student. If I did not submit grades on the formal grading sheets, students would not get credit for the class. So, of course, such institutional regulations are "limit situations" on critical practice inside formal schools and colleges. I have no choice but to submit final letter grades for each student because this is a state-regulated institution and students will not be awarded the degree unless they accumulate passing grades in each class. Summative assessment institutionally here is a letter grade but many of us consider a narrative summation more valuable to students, regarding where they started, what they did and how they ended from the teacher's point of view. I typically do not wait for a summative narration at the end to address the student. To me, the most important assessment is daily and weekly when 
students perform in class and on work handed in. I write a lot on their weekly homework papers encouraging them to rewrite, revise, re-think. I attach to their weekly writings different reading material focused on how they wrote and thought about the current issues. This week-to-week dialogue between an individual student and the teacher is where I spend most of my time in assessment.

3b. Eugene Matusov: From your book, it seemed that you selected the books that the students read, without input by your students, while they had freedom to pick up any topic for discussion within the books chosen by you. Was it because of the institutional pressure that you could not avoid (or not be able to sabotage) or because of your pedagogical belief in curriculum decided by the teacher as an absolutely necessary component of good education? If the latter, can you elaborate on that, please.

Ira Shor: Yes, I did select the two books for the class examined in When Students Have Power. I changed this habit soon after. The students heavily criticized me for one of the books chosen. In a subsequent class in "Coming-of-Age Narratives," I brought 25 different coming-of-age books to class the first night and asked the class to read each one for about 5 minutes, then grade that book on a scale of 1-10 according to how eager they are to read the next 5 minutes of that book, with 1 being "not interested" and 10 being "very interested." I collected that first night all their scores on all the books, tabulated them, and announced at the next class meeting which book got their highest votes and would comprise our reading list. In my first-year composition class, I routinely invite students to pick their own topics to research if they prefer not to study and write about the topic I introduce in class. I also invite them to use any background materials they like in researching their topics, not only the ones I hand out in class. In my doctoral seminar, I typically leave the last month of classes for students to nominate their own readings about the topic.

3c. Eugene Matusov: Do you think that education and critical dialogue can and must be imposed on all students or not? Why? What did you do when faced with disengaged students and why? Do you think that students should have a right on non-participation?

Ira Shor: Critical dialogue cannot be imposed on anyone! I pose problems around engaging themes for the students who then choose to dialogue or not about them. Many remain silent all term, some alienated from intellectual study in general, some alienated from the topic in particular, some just too tired or distracted to take part. They appropriate the right to not participate no matter what I do. I can't force them to speak with me and with others who accept the invitation to dialogue. It's useful to reiterate and expand what I just said about student refusal to dialogue: they haven't done the reading or the assignment for that day; they are bored with the class, with me, with the other students, with the themes under discussion, or with formal education in general; they are tired, hungry, sick or any combination of these factors; they are preoccupied with something else, like a test in another class, like a breakup with their romantic partners, like a sick family member, like paying their utility bills or paying their tuition. The problems I pose in any class typically do not provoke uniform participation; some reject or resist dialogue more, some less, as in all classes taught by all teachers, for a wide variety of reasons.

3d. Eugene Matusov: In some of our democratic (OSE) classes, our students argued against the majority rule and for making any decision in the class only about themselves on an individual basis, so nobody could impose on another student. Would you allow this way of decision making in your class, if you were the teacher? Why? Why not?

Ira Shor: The contract grading process I presented in my book When Students Have Power starts on the first class day. I hand out a typed sheet with proposals for grading plans and read aloud my 
proposals for $A, B$, and $C$ grades, then invite questions and amendments, which tend to be few the first night because this process is very unfamiliar to students. So, I ask students to take home the grading plans and spend some time reading them to see if they discover changes they want to propose. I announce that the second class meeting will begin with discussion of the grading plans. On the second day, I convene discussion on the plans and ask if anyone has changes to propose. Some classes have none; some, one; some several. I ask each student to state his or her change aloud and explain why it is an improvement over the item I wrote on the sheet. After the student speaks, I ask if anyone else thinks this change is good? Anyone disagree with it? The class has some discussion and then I call for a vote to see how popular it is. Majority votes carry the proposals but I also announce that any student can write his own or her own grading plan and negotiate it privately with me for the grade they want and the work they will do. So, individual students can chart their own grading plan if they like.

3e. Eugene Matusov: What if some or a majority of your students voted for traditional (non-democratic) regime in you class, would you follow their wish? Why? Why not?

Ira Shor: Of course, I have to follow their preference if a majority of students reject the grading plans. I cannot impose democratic relations against majority resistance. This has happened in some classes and they force me to become a traditional teacher like the ones they have had before.

3f. Eugene Matusov: What was the fate of your democratic pedagogical experimentations described in your 1996 book? What were success and challenges? How did your pedagogical problematics change and why?

Ira Shor: Conditions for teaching and learning, as well as for everyday life and raising families, deteriorated dramatically for me and for the working-class students at my college across the 45 years I have taught there. Students were paying higher tuition for lower quality education. Many were unable to afford tuition and had to drop out after the class began. It became harder and more hostile to be a teacher or a student-bridge tolls and mass transit rose in cost, as did textbooks and food in the cafeteria. Fewer students would stay with me after class for the very unique and useful After-Class Group I began and wrote about in When Students Have Power. I discovered that the ACG worked best with a minimum of 4 students and a maximum of 8 , but fewer than 4 typically volunteered in recent years. Students had to leave class immediately to go to jobs, to families, or to prepare for tests in other classes. Critical-democratic teaching and learning became a class luxury harder to practice here as the income inequality gap kept widening. Still, I begin each course with a presentation of the grading plans mentioned above.

3g. Jim Cresswell: In your book (1987a), you open with a history of the development of colleges. You seem to describe them as "warehouses" that placate the masses. Over the last thirty years, technology has changed classrooms so that there is more online participation and more ways to engage a wider student body (e.g. student forums). How would you reformulate (or not) your assessment from 1987 in light of classroom technologies?

Ira Shor: Billions have been spent on computer hardware, software, peripherals, and bandwidth since 1987, yet critical scholars and educators are still waiting for research confirming that computer applications enhance student learning and achievement. Such confirmation is irrelevant to the tech billionaires and their agents in the media and government who advocate more and more tech in schools. Scholar Larry Cuban from Stanford doubted the educational value of tech applications twenty years ago but such misgivings could not slow down high-tech entrepreneurs when tech applications are such 
a leading factor in profit-making. Tech entrepreneurs became hegemonic gods in our society in the last 30 years who successfully commanded the integration of technology into education at all levels despite the vast drain on declining district and campus budgets, despite scant evidence that such expenditures produce outcomes worth the cost. Tech has been a one-way monologue so loud and pervasive as to exclude critical dialogue about what tech applications to learning mean or engender, or who benefits.

Critical learning can integrate all kinds of tools into the needs of students and teachers involved in a process to question the status quo. Digital tech is a tool; so are books, pencils, chalk, blackboards, well-lit and clean classrooms, the voice of the teacher, etc. Freire's culture circles appealed to progressive authorities in impoverished Brazil of the 1950s because his method was inexpensive to deploy and fast to deliver basic adult literacy in only 30-40 hours of instruction. His tools included cheap Polish slide projectors to display the 10 original drawings which initiated dialogue. The projectors and slides were destroyed during the military coup of April, 1964 because they were considered subversive tools. I another instance, after the September, 1973 military coup in Chile, a folk instrument associated with the musicians supporting the Allende government, the churanga, was banned by the generals because it too was deemed a subversive tool. Tools, then, have to be examined critically and historically for the politics of their operation. Books are traditional tools of education now being displaced by digital reading devices; the political economy of digital preferences empowers the billionaire tech entrepreneurs, certainly, but neither the book nor the Nook reader are by themselves critical or uncritical as tools of pedagogy. We need to ask which tools are used in which ways for what purposes and with what results, to grasp the politics as well as the efficacy of a device or method. By themselves, then, books do not guarantee critical teaching or critical reading. A pen and paper to write an essay does not guarantee the development of a student's critical literacy. Chalk and blackboards do not guarantee critical teaching. Watching films does not guarantee media literacy. Digital tech does not guarantee anything critical about the process of learning. The only thing guaranteed is the gigantic cost of imposing such tech on education. In my judgment, the billions spent on successive generations of soonto-be obsolete tech would have been better spent reducing class size by hiring more teachers and building more classrooms; better spent guaranteeing a full-time librarian, a full-time nurse, a full-time social worker, and a new athletic center in all schools for kids to play and run around; better spent on outdoor education for inner-city kids especially; better spent on class trips and field projects. At the very least, research has confirmed that physical activities between classes enhances student attention and that small classes enhance the achievement of students, especially low-income ones, but the hegemonic power of tech in society ignores this research and forces tech purchases on schools regardless, at a time when the public sector budget is in decline.

3h. Jim Cresswell: The idea of empowering students is central to your work and dialogical pedagogy in general. Since the mid-1990's it seems (to me) like there has been an explosion of something like trade literature in higher education (e.g. the "Teaching Professor" group and the disciples of Maryellen Weimer). What strikes me as strange is how neo-liberal "client-centred" administrators have latched onto this work as an effective marketing tool and model for "service-delivery" that enhances student attraction/retention. The latter reduces students to commodities and there doesn't seem to be much discussion about incompatibilities between student empowerment and market-driven commodification. That is, this literature seems to empower students and yet it is simultaneously appropriated as a tool of objectification. Can you comment on this seeming paradox?

Ira Shor: You are exactly right. What we call "programmed learning" or sequential modules clued to single-student sequencing, has been appropriated as individualization of teaching and learning, now being called "personalized instruction" delivered digitally and paced according to the student's progress 
through the modules. Many of us in education call this virtual pedagogy "depersonalized learning" because students do not interact with actual persons called "real teachers." The students sit alone in front of screens without a professional adult educator observing and evaluating their activities inprocess, whose job it is to pull that student's extant learning forward into the next step of their development. Many years ago, Lev Vygotsky named this live learning interaction of the less-advanced learner with the more advanced teacher as "the Zone of Proximal Development." A computer screen can only feed to the student what the machine is pre-programmed to say and do. The peculiar genius of human beings, including teachers, is our ability to make on-the-spot, in-progress determinations and interventions based on our real-time observations. This is why the de-personalized individualized learning spreading now through tech buys and virtual teaching devices cannot equal the real teacher as a tool of instruction.

The ultra-individualization of virtual instruction fits the neoliberal thrust of the past four decades in school and society. Neoliberalism imposes strong market discipline on all sectors of society and human experience. This means micro-managing society so as to convert all activities into enhanced revenue streams for the private sector. Real teachers are human beings who are harder to manage than teaching machines; real teachers join unions and demand negotiated improvements in their work. Neoliberal government and business have imposed forty-five years of austerity on school, work, and everyday life, which means compelling the vast majority to settle for less, make do with less, and do more with less, so that the $1 \%$ in charge can capture more and more of the national wealth. Virtual teaching in schools and colleges fits this anti-labor neoliberalism very well, because fewer high-cost professional educators are needed as lower-skill tech coordinators replace them. The tech flloding into our classrooms may be used by ingenious critical teachers to develop students as activists who question knowledge and power in their society, but the virtual takeover of schooling is certainly not intended to propel such an outcome.

The conversion of public education into a feverish marketplace for digital tools has developed side-byside with the feverish privatization of public schools via the bogus charter mechanisms. If computer instruction is like fast-food for the mass of students, pre-packaged and delivered by low-cost labor, the entire public school itself is being appropriated as a revenue stream for private enterprise. Pushed by billionaires who spend vast sums recently to win local school board elections for privatization advocates, public schools are losing students, buildings, and tax funds to private entities called charter schools. The neoliberal battle cry of "individual parent choice" is the discursive weapon leading the dismantling of public education in America.

\section{Critical literacy vs. traditional literacy}

4a. Tara Ratnam: Literacy as a tool seems to have the potential to naturally awaken critical thinking (e.g., the print media played a pivotal role in mobilizing the people's urge into the constructive direction of working to liberate India from British rule). Then, if literacy comes with a critical edge inherent in it, is it useful to make a distinction between critical literacy and traditional literacy? Do you think, whether literacy is critical or not depends on the disposition of the person who approaches it one way or the other?

Ira Shor: I have read a little about the colonial education offered to native peoples by their European colonizers, who beat children caught speaking their native languages, and which oriented the students to value European culture in literature and history. On the whole, though, I am unfamiliar with this aspect of Indian history so cannot comment directly, unfortunately, though it is a very important topic. I would want to study what kinds of publications circulated when among which populations and what kinds of 
political activities followed from these interactions. I witnessed unsupervised literacy erupt in Russia in 1989 when I traveled there and saw the streets of St. Petersburg flooded with publications and speakers of all kinds criticizing the Communist regime still in power then. I am also aware of literate activities as tools of resistance in England in the 1790s among peasants, artisans, and tradesmen, as reported in E.P. Thompson's magisterial The Making of the English Working Class. At that time, "Corresponding Societies" emerged as part of the popular unrest lasting through the Chartist movement of the $19^{\text {th }}$ Century. Not knowing how to read was no impediment to participating in oppositional politics because at local furtive pub meetings, a literate peer read aloud news and reports of resistance elsewhere. In this period and for a century or more afterward, the ruling elites suppressed radical publications and their authors precisely because such material could spur opposition. Similarly, slave owners in the American South prior to 1865 also forbade slaves to learn reading and writing because they feared the rebellious consequences of such tools. After Emancipation, former slave owners opposed teaching any critical subject matters to slaves, which the white supremacists labeled "sociology" (studying social conditions), and insisted only on the ABC's-restricted literacy devoid of problematic content. At this moment, sorry to say, few of my working-class students at Staten Island read newspapers in print or online, so my critical pedagogy includes scaffolding critical curiosity about events reported in the news.

\section{Paulo Freire and critical pedagogy}

5a. Eugene Matusov: Paulo Freire has been criticized by several scholars (e.g., Facundo 1984, Matusov 2009) for his work in the Communist Guinea-Bissau. These critics alleged that Freire actively engaged in promoting communist totalitarianism in his "critical pedagogy" of literacy there, brainwashing illiterate African peasants with the Communist propaganda. Would you agree with this criticism? If so, how would you reply to it on your own and Freire's behalf - how did it happen that Freire's critical pedagogy became totalitarian? If not, why not?

Ira Shor: Freire has spoken for himself on this matter. I was at one of his public forums where the issue with Guinea-Bissau was raised and Freire also addressed in his books with Macedo and with Faundez. Freire reported opposing the revolutionary regime's use of a European language, Portuguese, as the linguistic foundation of its literacy program and schooling. Freire thought this would have antidemocratic outcomes which privileged the neo-colonial European elite which is typically at the center of anti-colonial opposition. Freire strenuously opposed anti-democratic, anti-dialogic leadership on the left, in Pedagogy of the Oppressed. He disdained dogmatic and doctrinaire leftists, referring to their arrogant certainty of possessing the truths needed by the masses, calling their method "injections of revolutionary wisdom." Freire himself was a modest and reluctant "icon" who preferred not to lecture at the many forums and assemblies he was invited to. He wanted the people there to pose their own questions and engage each other in robust dialogue about how to consolidate themselves into stronger opposition to the status quo. He knew that he could not direct people politically into action when he had arrived as a stranger from far away. This was the modest posture Freire took throughout the years I traveled and worked with him, when I heard him express dismay at the way the Guinea-Bissau regime handled its literacy program.

5b. Robi Kroflič: What is your evaluation of Freire's concept of empowerment as a "tool" for emancipation, since some new scholars (Ellsworth, Ranciere, Biesta) are extremely critical about the presumption of a teacher "being in a position of power" and give knowledge and competences to a pupil to become powerful...

Ira Shor: Freire did not believe that he or any teacher could liberate anyone in the classroom. Teaching was not that powerful a tool in any society. Formal education or classroom instruction could not be by 
itself a "the lever to change society," he said in our book A Pedagogy for Liberation. For Freire, education had to be associated or coordinated with mass movements which were the tools for political empowerment in society. To Freire, education mattered most when it was inside a political movement which socialized oppositional consciousness developed inside and outside the classroom, that is, gave theorizing a practical platform in the midst of forces contending for power. Freire made it clear in our dialogue book that education counted most when it was embedded in mass movements contending for social justice. Institutional classrooms separated from ongoing movements and distant from community life could not match the potential empowerment of a political movement. Freire's original literacy circles emerged as part of great political upheaval in Brazil in the 1950s and early 1960s. A democratic coalition of popular forces was consolidating from the bottom up to radically change Brazilian law and society. Freire's literacy project 1963-1964 was undertaken for the democratic government of Joao Goulart. By 1965, Freire's program would have set up 20,000 literacy circles nationwide, alphabetizing perhaps a million new lower-class voters who had to read and write to be allowed to vote for the first time. The concrete empowerment of peasants and workers through literacy at that time involved overcoming the Brazilian Constitution's prohibition on illterates voting. Before this project could radically alter the electorate with a vast new constituency oriented to the left, Freire's program was destroyed by a military coup and Freire was jailed. Freire's education work was was part of a pre-revolutionary moment in Brazil empowered by its connection to mass movements which it in turn empowered.

5c. Judith Green: What are your current views on critical pedagogy and critical literacy?

Ira Shor: Answered above vis a vis the long neoliberal imposition of market discipline on school and society, reducing education budgets, diverting school moneys to private revenue streams. Larger class sizes and fewer professional educators are undermining the capacity of the public sector in education, in affordable housing, in mass transit, and in health care. This long-term assault by the top on the living standards of the bottom partly explains the populist uprisings in recent elections here and in Europe.

5d. Judith Green: Can you frame what kinds of knowledge, understandings and perspectives you have developed that teachers need to know, understand and undertake if they wish to promote equity, equality, and high quality education for all?

Ira Shor: Understand social justice as an orientation towards democracy, equality, ecology, and peace. Develop syllabi which install those values in classroom practices. Support mass movements which are mobilizing under that agenda. For public school teachers especially, build rank-and-file organizations at the school and district levels which can oust the current renegade leadership of the two large teacher unions, the AFT controlled by the Randy Weingarten clique and the NEA leadership controlled by the Lily Eskelsen Garcia clique.

5e. Antti Rajala: In Freirean pedagogy, how much emphasis should be placed on specific injustice experienced by the students themselves vs. general injustice in the society?

Ira Shor: The most compelling themes in a learning process are those with the closest relevance and meaning to the students. The more general and abstract subject matters become, the more distant they are from the immediacy which captures students' recognition of what is at stake. Freire used the term "hinged themes" to denote connecting local generative themes to their larger social contexts, but was clear that critical literacy should begin with the local. 
5f. Antti Rajala: How can Freirean pedagogy be used in classrooms that are heterogeneous with respect to students' socioeconomic and cultural backgrounds and where some students are more privileged than others (e.g., economically, politically, academically, majority-minority, disabled-body-abled)?

Ira Shor: If at all possible, find something the students have in common: lunch hour? Food preferences? Sexual encounters? Family life? Search for jobs during and after schooling? Also, try to discover a common project they can engage in, for example, constructing an exhibition or putting on some kind of public performance, or interviewing people in the community, or redesigning the physical premises to achieve an improvement in their facilities.

5g. Antti Rajala: Freire speaks about reflection and action as dimensions of praxis. Reflection seems to be much more emphasized in regular schooling. How would you advise teachers working in the institutional constraints of public schooling about how to broaden the scope of instruction to involve also transformative action? What concrete projects could be realized in such conditions?

Ira Shor: Freire considered classroom study as "theoretical action," by which he meant dialogic action to develop how we perceive ourselves in the world, selves-in-society and society-in-selves. The critical classroom is first of all action on consciousness, which Freire defined as "intentionality," which is similar to Bourdieu's notion of "habitus," or the suite of preferences, dispositions, and orientations through which we understood the meaning of experience and acted in and on our experiences. So, to begin, we can say that critical classrooms which question the status quo are by definition actions for externalizing and rethinking the consciousness we bring to class, the consciousness always already extant. By proposing to students in my classes that we negotiate the curriculum or co-develop the sylla bus or the grading process, I am offering action on the concrete terms through which we constitute the learning process itself, offering the classroom as a kind of constitutional convention on the class itself. These practices offer some kinds of action as starters. Other kinds of action can be contemplated, like acting on the campus or on the community, or on the city or in the larger society. All kinds of projects can be imagined for such actions and ongoing actions already underway outside the classroom can be suggested or integrated. The compelling issue here is what Freire called "limit-situations," that is, political and institutional limits on action to change things or to effect conditions. For instance, in his time, Freire faced limits on the funding available to set up literacy circles nationwide, and he faced political limits vis a vis the conservative opposition to such circles operating. Eventually, the elite and its military crushed the operation entirely. In any setting where critical educators and activists work, there are political forces and limits we must take account of. How far can we go in questioning the status quo? What are local limits and who are local allies and adversaries?

5h. Lynn Cohen: For Freire one of the problems with schooling was the non-dialogic nature of pedagogy. Similar to the U.S., it appears that Brazil has increasingly adopted a pedagogy of submission. Studies have indicated that preschool curriculum is not being taught in dialogue with teachers and children, but rather a top-down didactic approach is transpiring in Brazil. What has happened to create such a nondialogic approach?

Ira Shor: Retreat of the progressive forces in Brazil and in the Workers Party which first installed Freire as Secretary of Education for the City of Sao Paulo in 1989. Without progressive political forces for change in the political party and in Brazil, it is much more difficult to move schools or any other institution in society in a humane direction. 


\section{Language and thought}

6a. Sue Brindley: Can policy (of whatever persuasion) claim thought if it claims language? Thinking here of Durkheim's sacred and profane discourse and the ways in which education policy makers seem to have excised critical engagement ('sacred') from professional discourse.

6b. Sue Brindley: Can education now resist centralisation and managerialism - or is it too late?

6c. Sue Brindley: Do you agree with Lyotard's claims that the meta narrative of science defines knowledge in this era - with the consequent dismissal of any other type of knowledge as legitimised? If so, why, and if no, why not?

Ira Shor: Not sure how to respond to the Durkheim reference, sorry to say. About centralization, yes, it has grown much worse in past 45 years of neoliberalism. Only a bottom-up movement of school parents and school teachers will be able to win power for schools to govern themselves and for professional educators to operate their own creative classrooms. The Opt-Out Movement of mostly mothers since 2011 against the grotesque takeover of public schools and classrooms by standardized testing is a good example of bottom-up opposition fighting top-down authorities to a standstill. This battle is still underway. Not quite sure how to respond to the Lyotard question except to say that quantitative discourse certainly dominates in this neoliberal age. Everything must be tested, evaluated, measured, assigned a rank, all means by which authorities exert domination over masses of people.

\section{Discussion}

By Eugene Matusov, Ana Marjanovic-Shane and Jim Cresswell

The interview questions and answers from Shor touch on many themes and ideas and we would like to discuss some of these ideas. Our position is that there are two themes where generative points of tension emerge between what Shor has said and what can be understood about DP.

\section{Power of Pedagogues}

One of the key points where DP aligns with critical pedagogy is the concern with equalizing teacherstudents power in the classroom. Shor writes about giving students power and DP involves eroding the status of the privileged instructor. Both cases mean to reduce the power differential among students and teachers such that students have agency and power in the classroom. It looked, to us, like this equalizing was not as close as it seemed because Shor seems to see education as molding students in certain preset agenda and value system of social justice. For example, he wrote that, "[t]eaching against the unequal status quo and for majoritarian agency is of course another way to define critical pedagogy as Paulo Freire proposed it. In doing this, critical-democratic educators will have to generate quality and equality at the same time." What if a student disagrees with this goal of education? Consider also how he wrote: "...my critical pedagogy includes scaffolding critical curiosity about events reported in the news." What if a student's curiosity is directed primarily toward socialization in a targeted practice without necessarily a critical stance on it (e.g., learning to speak fluent French)? On the one hand, this is an exceptionally exciting comment and it would have been great to hear more about "scaffolding" of critical curiosity. On the other hand, scaffolding critical curiosity could point to a deficit model with the instructor knows a priori what is missing in the students. It opens the door to the implication that, if education is successful, all students seemingly MUST be against inequality and all students MUST be active agents for social justice. This looks like a view of education that diverges from DP (at least in Bakhtin's framework) where education includes a critical examination of the self, life, world and society in an internally persuasive discourse (BIG Dialogue) 
without any preset agendas. In a Bakhtinian dialogic pedagogy a diversity of educational goals is welcomed because it promotes a deep and critical dialogue about the nature of education with the students. In contrast to Shor's approach, a Bakhtinian dialogic pedagogy does expect that all students have to be committed to social justice or even to critical examination. This distinction lead to a surprise because Shor, a social justice warrior, seemed to place himself closer to an oppressive practice than we would see in DP. Consider, for instance, his discussion of grading where he engages his students in the summative assessment enforced by the institution. He does not involve his students in critical examination of grading (i.e., summative assessment) in education. He does not try to sabotage this kind of oppressive practice by, for example, giving all students unconditional A's at the beginning of the class, which some in DP do. There seemed to be an ambiguity, if not even internal struggle, with regard to the usefulness of summative assessment that is often seen in DP. DP would involve emphasizing the issue of whether summative assessment is necessary for education or not, and if so, the times when it is bad (or good) and who it is good (or bad) for. Overall, an analysis of Shor's approach suggests that more power is left in the hands of well-meaning pedagogues relative to DP (at least committed to the Bakhtinian framework).

An instance where this divergence could be seen vividly is in how Shor engaged the discussion of the numerous tragic failures of social justice movements that give rise to power of the Communist totalitarianism Shor referred to such moments as "totalitarian excesses," which seems to imply that "moderate Communist totalitarianism" would be fine. It looks like he equated Capitalist issues of the West with Communist issues of the East with comments like: "We have capitalist oligarchies in the West and have witnessed the collapse of communist oligarchies in the East". This sort of position runs the risk of ignoring the qualitatively different contexts such as mass Gulag oppression, mass murder in the Communist regimes, and lack of many freedoms. People tried to escape from the Communist regimes en masse to the West liberal democracies, however flawed they were, and not the other ways around. This leaves the impression that Shor may represent the Old Left that takes less head from the $20^{\text {th }}$ century mass tragedies emerging form the socialist-communist social justice movements, viewing them as excesses or aberrations and not as major flaws of the social justice movements themselves. There seems to be a lack of critical self-reflection in the Old Left social justice approaches. Underlying this position could be a comfort with pedagogical power that is more often carnivalized in DP.

\section{'Leftist' Positioning}

An admirable feature of Shor's work is his emphasis on the legitimacy of students' non-participation in dialogue or study on a topic. Without students feeling free to participate or not to participate in a genuine dialogue or genuine education, genuine education may not be possible. It is much better to expect diverse forms of participation and non-participation, which is a hallmark of DP. This point of agreement is also a point where Shor and DP seem to emerge. In short, it looks like Shor takes a position as a pedagogue that is politically left, whereas DP would appreciate diversity in teachers' and students' political positioning, including apolitical ones.

Consider how, instead of appreciating, politically promoting, and critically examining diverse values (not just linguistic forms) - both hegemonic and marginal - Shor seems to want to instill the hegemonic cultural capital in marginalized students. DP could see this educational ideal seems to be in equal distribution of the hegemonic cultural capital for the marginal students through wrapping hegemonic ideas into marginal people's linguistic forms. These hegemonic ideas could involve "critical teaching" indoctrination into his social justice activism. The result is that DP would see Shor's treatment of dialogue as running the risk of being an instrumental view: a pedagogical tool of accessing cultural capital for marginalized students. Following from this sort a view is the potential to adopt an instructional strategy of molding people into preset social justice agendas that are unilaterally studied the oppressed by the educator 
prior to encounter to his/her students from marginalized social groups. Consider how Shor argues that "Dialogue fits into a sequence of teaching-learning which in the Freirean mold begins with the teacher studying the students before she presumes to teach them." DP would respond to such an espoused pedagogy with the challenge that it is essentially monologic, aiming at molding the students into preset social justice agendas by using dialogic interaction and instruction for achieving this monologic pedagogical goal.

Consider how it is possible to wonder about Freire avoiding responsibility for his own action of oppression and active participation in a totalitarian regime, which becomes possible when one's own position is not challenged. At times, it looks as if Shor challenges DP by representing an "Old Left" that may be disinclined to learn much from wrongs and crimes of the social justice movements of the $20^{\text {th }}$ century. Shor, nevertheless, makes a very thought-provoking point that good education is some kind of "luxury" requiring freedom for the students from their survival and necessity worries: "Critical-democratic teaching and learning became a class luxury harder to practice here as the income inequality gap kept widening." The Greek word "school" means leisure. Genuine education may require genuine leisurely life, which is not available for a high majority of the US and world population (even for rich ones) and this points to the potential privileged pedagogue. The risk, from a DP perspective is that we could miss the tension between the notions of diversity and the notions of social justice. Any possible tensions could be attributed by Shor to "neoliberalism." In our view, social justice movement mainly focuses on issue of equality (in a broader sense that may include equity, inclusion, and so on), "Equality and inclusion remain the unfinished tasks of democratic movements from below." Meanwhile, the concept of "diversity" involves inequality, exclusion, pluralism, differences in values, liberties, and so on. We see important tensions between these two notions and such tensions should be explored rather than ideologically dismissed as a manifestation of "neoliberalism."

Shor's positioning highlights an important discussion about the relationship between deconstructing and re-constructing in critical and DP. This relationship is a complex one, but it looks as if Shor emphasizes re-construction (i.e., a positive new construction for a just society, for example) over deconstruction. If it is true, DP is challenged with a view that may involve the opposite relationship to the ontological DP. DP supposes that de-construction is primary for genuine education, while re-construction is secondary, accidental, and by-productive in education (it is not true in other practices). DP emphasize education that sees its end in itself as a human existential need. Shor advocates for the opposite perspective, making education instrumental $-a$ tool to build an equal and just society.

\section{Selected Bibliography}

Shor, I. (1987a). Critical teaching and everyday life. Chicago: University of Chicago Press.

Shor, I. (1987b). Freire for the classroom: A sourcebook for liberatory teaching (1st. ed.). Portsmouth, NH: Boynton/Cook.

Shor, I. (1992a). Culture wars: School and society in the conservative restoration 1969-1984 (University of Chicago Press ed.). Chicago: University of Chicago Press.

Shor, I. (1992b). Empowering education: Critical teaching for social change. Chicago: University of Chicago Press.

Shor, I. (1996). When students have power: Negotiating authority in a critical pedagogy. Chicago: University of Chicago Press. 
Dialogic \& Critical Pedagogies: An Interview with Ira Shor Ira Shor, Eugene Matusov, Ana Marjanovic-Shane, James Cresswell

Shor, I., \& Freire, P. (1986). A pedagogy for liberation: Dialogues on transforming education. South Hadley, MA: Bergin \& Garvey Publishers.

Shor, I., \& Freire, P. (1987). What is the "dialogical method" of teaching? Journal of Education, 169(3), 11-31.

Shor, I., \& Pari, C. (1999a). Critical literacy in action: Writing words, changing worlds. Portsmouth, NH: Boynton/Cook Publishers.

Shor, I., \& Pari, C. (1999b). Education is politics: Critical teaching across differences, K-12. Portsmouth, $\mathrm{NH}$ : Boynton/Cook Heinemann.

Shor, I., \& Pari, C. (2000). Education is politics: Critical teaching across differences, postsecondary. Portsmouth, NH: Boynton/Cook.

\section{(c)) EY}

New articles in this journal are licensed under a Creative Commons Attribution 4.0 United States License.

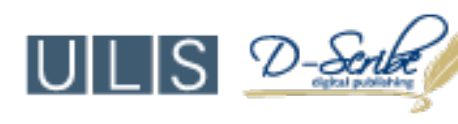

This journal is published by the University Library System, University of Pittsburgh as part of its D-Scribe Digital Publishing Program and is cosponsored by the University of Pittsburgh Press. 